Agnieszka Marczak

Muzeum Etnograficzne im. Seweryna Udzieli w Krakowie

\title{
Nasze życie w czasach zarazy. Kilka słów o projekcie ${ }^{1}$
}

\section{Pomysł}

„Nasze życie w czasach zarazy”2 to inicjatywa, która powstała spontanicznie w marcu 2020 r. w Muzeum Etnograficznym im. Seweryna Udzieli w Krakowie $^{3}$ jako odpowiedź na potrzebę dokumentowania szybko zmieniającej się rzeczywistości w dobie pandemii. Mieliśmy poczucie, że czas ogromnego zainteresowania mediów wszelkimi treściami dotyczącymi koronawirusa, to również dobry moment na to, by poprzez nasze działania, zaprezentować szerszej publiczności, czym jest Muzeum Etnograficzne.

Muzeum Etnograficzne w Krakowie to przede wszystkim miejsce deponujące opowieści o życiu od połowy XIX w. do dzisiaj na terenach należących obecnie do Polski. Te opowieści mają charakter wizualny, są reprezentowane przez rzeczy, związane z codziennością zwykłych ludzi, co sprawia, że każdy może odnieść muzealną narrację do własnego życia. Dlatego osoba zwiedzająca muzeum ma możliwość poruszania się po wystawie jako ekspert, znajdujący podobieństwa i różnice pomiędzy atrybutami

\footnotetext{
${ }^{1}$ Ponieważ projekt „Nasze życie w czasach zarazy” wciąż trwa, a na analizę i naukowe podsumowanie zebranych materiałów jeszcze przyjdzie czas, pozwolę sobie tutaj na bardziej osobistą perspektywę.

${ }^{2}$ Dalej będę posługiwała się również skróconą wersją — „Nasze życie”.

${ }^{3} \mathrm{~W}$ dalszej części będę posługiwała się zamiennie: Muzeum Etnograficzne w Krakowie, Muzeum albo MEK.
} 
codzienności dawniej i dziśs ${ }^{4}$ Zatem muzeum etnograficzne, będąc blisko człowieka, ma duży potencjał angażowania go w swoje projekty. Kiedy więc myśleliśmy nad działaniami skierowanymi na badanie rzeczywistości społecznej w pandemii, chcieliśmy, by wiedza, którą będziemy gromadzić, była współtworzona z naszą publicznością. Z takiej postawy narodził się pomysł na projekt „Nasze życie w czasach zarazy”, w którym podkreślamy, że doświadczenie życia w czasie pandemii jest dla wszystkich wspólne, także dla nas — badaczy i muzealników.

W przeciwieństwie do innych projektów realizowanych w MEK, w przypadku „Naszego życia” prace koncepcyjne nad procesem badawczym (osadzeniem badań w teorii, wybraniem metod i technik oraz sposobu analizy materiału) nie trwały długo. Kosztem ewentualnych błędów podczas pracy badawczej, wynikających z pośpiesznego planowania, chcieliśmy jak najszybciej rozpocząć badania, mając cały czas na względzie, że sytuacja związana z pandemią jest dynamiczna i zwlekanie z rozpoczęciem działań może wiązać się z przegapieniem pewnych szybko zachodzących w życiu społecznym procesów.

Nie da się ukryć, że wybranie metody badawczej stanowiło dla nas pewne wyzwanie. Otóż Muzeum Etnograficzne od wielu lat prowadzi projekty badawcze, w których główną rolę odgrywają wywiady oraz obserwacje uczestniczące. Tymczasem, kiedy w Polsce wprowadzono społeczną kwarantannę, bezpośredni kontakt z naszą publicznością był utrudniony, a właściwie niemożliwy. Dlatego zaistniała potrzeba znalezienia innej formy, która umożliwi nam badanie rzeczywistości bez spotykania się z uczestnikami kultury, a jednocześnie zapewni swobodę wypowiedzi badanych tak jak ma to miejsce na przykład podczas wywiadu etnograficznego.

\section{Kwestionariusz „Nasze życie w czasach zarazy”}

Postanowiliśmy wrócić do korzeni naszego Muzeum i pracy terenowej jego założyciela — Seweryna Udzieli, który badając życie mieszkańców polskich wsi pod koniec XIX w., korzystał z metody kwestionariuszowej. Inspirując się rękopisami Udzieli, stworzyliśmy anonimowy kwestionariusz „Nasze życie w czasach zarazy”, składający się z 45 pytań, w większości otwartych. Znalazły się tam zagadnienia dotyczące m.in. rytmu i organizacji codzien-

\footnotetext{
${ }^{4}$ Należy podkreślić, że mam tu na uwadze osoby najczęściej odwiedzające MEK, a więc pochodzące z tego samego kontekstu kulturowego, co obiekty prezentowane na wystawie stałej, która przede wszystkim dotyczy życia na terenach obecnej Polski na przełomie XIX i XX w.
} 
ności, pracy, nauki, życia społecznego. Pytania o to, czy w trakcie pandemii zmieniło się postrzeganie domu i relacji z innymi ludźmi, o sposoby radzenia sobie ze stresem, a także pytanie o obrazy z pandemii, które na długo zostaną w pamięci. W kwestionariuszu, oprócz pytań otwartych, znalazło się kilka pytań zamkniętych (m.in. o płeć, wiek, miejsce zamieszkania) oraz kafeterii z prośbą o zaznaczenie na skali Likerta poziomu zainteresowania m.in. informacjami dotyczącymi pandemii. Zdajemy sobie sprawę, że dla badaczy bardziej doświadczonych w metodzie kwestionariuszowej i w badaniach ilościowych, kwestionariusz „Nasze życie” może mieć wiele wad, np. jeśli chodzi o układ czy stopień precyzyjności pytań. Niemniej jednak, należy zauważyć, że w związku z potrzebą szybkiego rozpoczęcia badań, nie było też możliwości na dokładniejsze przetestowanie metody na próbie ${ }^{5}$. Kwestionariusz został zamieszczony na bezpłatnej platformie Google Forms 27 marca i był aktywny do 30 czerwca 2020 r. W tym czasie zebrano 1523 odpowiedzi.

Wkrótce po uruchomieniu kwestionariusza, uznaliśmy, że chcielibyśmy na bieżąco dzielić się z naszą publicznością zebranymi danymi. Zaczęliśmy więc publikować tzw. „Wycinki”, które w sposób przekrojowy prezentują tematykę poruszaną w kwestionariuszach. Te kilkanaście postów zamieszczonych na stronie internetowej MEK ma charakter informacji zwrotnej, dającej znać respondentom, że ktoś czyta ich opowieści i reaguje na nie. Poniżej zamieszczam cztery przykładowe „Wycinki”.

\section{Wycinek I}

„Co słychać?”

\subsubsection{0, piątek}

Pytanie „Co słychać?” zawsze wydawało mi się po prostu próbą zagajenia rozmowy. A jeśliby potraktować je serio?

Wśród wypowiedzi na temat tego, co zapamiętamy z czasów epidemii, pojawiają się także te dotyczące dźwięków. Reakcje wpisywane na gorąco, bez koniecznego dla budowania pamięci dystansu (przecież jeszcze nie wiemy, co będzie dalej, co naprawdę w nas zapadnie), otwierają nas na bardzo osobiste doświadczenia. Kogoś dotknęło znalezione na Twitterze dźwiękowe nagranie kaszlu chorego na ko-

\footnotetext{
${ }^{5}$ Podczas zbierania odpowiedzi na kwestionariusz wprowadziliśmy w nim drobne korekty, a także przetłumaczyliśmy go na Polski Język Migowy.
} 
ronawirusa, nagrane we Włoszech. Kogoś innego, słyszany przez telefon głos współpracowniczki, która nie mogła złapać oddechu. To jednorazowe, mocne doświadczenia. Ale osiadają w nas także te powtarzane do znudzenia, jak ścieżka dźwiękowa włączanej codziennie gry komputerowej czy kilka piosenek, które każdego dnia między 13 a 16 serwuje mieszkańcom pewnego bloku jeden z sąsiadów („Niestety trudno się przy tym pracuje” - czytamy w komentarzu).

Dźwięki uświadamiają nam, że ściany naszych mieszkań i domów nie oddzielają nas szczelnie od wspólnej przestrzeni, z której możemy teraz korzystać w sposób mocno ograniczony. W wielu wypowiedziach powracają: sygnał karetki (także jako „nieustająco przejeżdżające karetki”) oraz komunikat, informujący o konieczności pozostania w domu, emitowany z megafonów wozów policyjnych i strażackich („kojarzy się z filmami o apokalipsie”, „czułam się jak na kronice filmowej z czasów okupacji”), bicie dzwonów.

Odkryciem podzielanym przez wielu uczestników badań jest cisza. Cisza w najbliższym otoczeniu, na pustych ulicach, placach. Cisza, która niepokoi i taka, która daje ukojenie. Cisza wypełnia miejsca, z których ustępuje hałas (teraz wielu z nas zdało sobie sprawę, że codziennie nam towarzyszył), ale też stwarza przestrzeń dla dźwięków, które wcześniej nam umykały. Do naszych uszu dociera śpiew ptaków. Przecież jest wiosna.

W karmniku, który zawiesiłam jeszcze zimą dla sikorek, rozgościły się zięby. W Przewodniku Collinsa znalazłam wczoraj informację, że piosenka zięby jest „wysoce charakterystyczna, dość niezmiennie i niestrudzenie powtarzana, czysta, głośna (...), całość zakończona dziarskim zawijasem: zit-zit-zit-zit-set-set-set-czat-cziteriidia”. Rzeczywiście, jakoś tak to brzmi.

A co u Was słychać?

Autorka: Dorota Majkowska-Szajer

Tekst powstał na podstawie odpowiedzi na 38. pytanie ankiety, które brzmi: „Czy jest jakiś obraz (dźwięk, sytuacja, fakt), z tego czasu, który szczególnie Cię dotknął lub zapamiętasz?”. 


\section{Wycinek II}

„Strategie dezynfekcji”

16.04.2020, czwartek

Na liście zapachów kojarzących się nam z czasem epidemii zdecydowanie nie ma tłoku. Jak dotąd (połowa kwietnia 2020) jest na niej tylko zapach środka odkażającego, niekoniecznie w roli herosa. Ktoś poskarżył się: „Zacząłem odbierać zapach środka do dezynfekcji rąk jako przykry. Wcześniej wywoływał we mnie przyjemne skojarzenia”.

Kwestia aseptyki pojawia się w odpowiedziach na pytanie o czynności, jakie w czasach zarazy wykonujemy bezpośrednio po powrocie do domu. Odpowiadamy zaskakująco zgodnie. Oczywiście myjemy ręce. Jedni myją „po prostu”, inni robią to „dokładnie” (lub „dokładniej niż zwykle”), inni „starannie”, jeszcze inni „długo”, ktoś nawet „obsesyjnie”.

Ważny jest system, który pozwala poczuć, że panujemy nad sytuacją: „Mam procedurę mycia i odkażania: rąk, klamek, łap psa”. Strategia osiągania bezpiecznej czystości jest przemyślana, logicznie zaplanowana, ale i czasochłonna: „Zostawiam zakupy w korytarzu, ściągam buty, płaszcz. Natychmiast myję ręce, potem odkażam klamki, włączniki światła, etui z kartą płatniczą, klucze, zakupy, telefon. Piorę maseczkę. Na koniec ponowne mycie rąk. Całość czasami trwa 40 minut”. Ktoś, opisując podobny rytuał, zauważa: „Żmudna praca, jak na jedno wyjście z domu ;)”.

Jeśli dysponujemy większą przestrzenią, dzielimy ją na strefy bezpieczeństwa: „Utworzyłam na klatce schodowej miejsce na pozostawianie butów oraz miejsce na kapcie. Postawiłam również wieszak na kurtki pół piętra niżej”. Albo: „Odzież wierzchnią i torby na zakupy wietrzę przez kilka godzin na balkonie”. Albo: „Mam wydzieloną jedną „brudną” łazienkę na parterze, w której teraz jest mydło w płynie i papierowe ręczniki, więc po powrocie myję ręce (tak lekarsko i śpiewając Wlazł kotek na płotek, by odmierzyć czas mycia)”.

Czasami ogarniają nas wątpliwości, czy system jest doskonały: „W trakcie różnych czynności, po powrocie z zewnątrz, myślę czego dotykam i czy to było ze mną w sklepie. Na przykład, kiedy zwijam torbę zastanawiam się, czy jest na niej wirus. Ale nie piorę jej”. Bywa, że jesteśmy przytłoczeni nadmiarem starań: „wcześniej prałam ubranie, już tego nie robię”. 
Obserwujemy się przy tym z zaciekawieniem: „W ostatnich dniach do moich nawyków weszło nastawiane garnka z wodą do wygotowania uszytych maseczek. Tak wygląda każdy wieczór teraz”.

I dostrzegamy, jak w ciągu 30 dni zmieniło się nasze życie: „Zamykam drzwi, dezynfekuję ręce środkiem na bazie alkoholu, zdejmuję buty, kurtkę, idę umyć ręce mydłem, witam się z kotem zniecierpliwionym moim ‘ignorowaniem’ tego, że chce być głaskany”. Albo „...krzyczę do dzieci żeby się nie zbliżały dopóki nie umyję rąk".

Ciekawe, jak będzie za kolejny miesiąc.

Autorka: Katarzyna Piszczkiewicz

Tekst powstał na podstawie odpowiedzi na 9. pytanie ankiety, które brzmi: „Co robisz zaraz po powrocie do domu?”.

\section{Wycinek III}

„W czterech ścianach”

23.04.2020, czwartek

Jeszcze niedawno, choć z dzisiejszej perspektywy wydaje się, że w innej epoce, na warsztaty do muzeum przychodziły dzieci. Jednym z punktów programu była opowieść o warunkach życia w przeciętnej krakowskiej chałupie. Pamiętam dzieciaki, które łapały się za głowę: jak w tak niewielkiej przestrzeni mogła się pomieścić wielopokoleniowa rodzina?! Zatem, by zagospodarować ich niedowierzanie, oznaczaliśmy w chałupie miejsca, gdzie można by ułożyć wszystkich do spania: na ławie, w kołysce, za piecem...

Ciasnota to pojęcie względne.

Na kwestionariuszowe pytanie: „Jak się czujesz w domu?” padają odpowiedzi, które można by umieścić na kilkupunktowej skali ocen od „doskonale”, ,cudownie” przez „,bardzo dobrze”, „normalnie”, „ok”, „jak zawsze” po „źle”, „okropnie” i „fatalnie”. Ostatnio zaczęło nam się też robić ciasno: „w domu jest jakby mniej miejsca”. „Nie wiadomo, na ile to schronienie, a na ile więzienie”.

Dla jednych dom to azyl, sprzymierzeniec $\mathrm{w}$ walce $\mathrm{z}$ epidemią, dla innych poczekalnia, a nawet łódź podwodna. Wiele osób czuje się w domu niczym w klatce (jak „chomik” albo „papuga”). Niektórzy 
przyznają wprost: „czuję się jak w więzieniu”, więzieniu „dziwnym”, „bez strażników”, ale „wygodnym”, a nawet „luksusowym”.

„Ile można siedzieć w czterech ścianach?” — ktoś pyta retorycznie.

Czasem czujemy się bezpiecznie i przytulnie, innym razem „siedzenie w czterech ścianach doprowadza do szału”. Brakuje nam świeżego powietrza, bliskich, ale przede wszystkim decyzyjności: kiedy i gdzie wyjść.

Nie bez znaczenia jest miejsce zamieszkania. W blokach czujemy się gorzej, zwłaszcza na małym metrażu, choć są i tacy, dla których 30 $\mathrm{m}^{2}$ we dwoje i z psami to przestrzeń, co prawda, niewielka, ale sprawiająca radość z bycia razem.

Niektórych przytłacza „betonoza za oknem”, snują marzenia o własnym domu z ogródkiem. Kawałek przydomowego trawnika staje się synonimem rajskiego ogrodu, niemal wiecznej szczęśliwości, a jego marna, ale jednak, reprezentacja w postaci balkonu to dla mieszkańców blokowisk luksus.

Dobrze w domu czują się domatorzy (choć i oni mają „powoli dość”) oraz osoby deklarujące udane życie rodzinne. Niektórym doskwiera samotność, innym wręcz przeciwnie: nie mogą wytrzymać z domownikami. „Bycie non stop z partnerem sprawia, że czasem denerwuje, nawet jak kichnie”. Stała obecność bliskich niektórych „dobija”, zwłaszcza nastolatków i studentów. A dzieci, spędzające teraz całe dnie w czterech ścianach, obijają się o nie jak wolne elektrony, doprowadzając rodziców „do szału”.

Ważna okazuje się więc możliwość „odizolowania od reszty domowników (tak, żeby nie wiedzieć, czym oni się zajmują i móc się w pełni poświęcić własnym zajęciom)”.

Zatem próbujemy różnymi sposobami powiększyć swoją przestrzeń życiową. Niektórzy robią generalne porządki, wyrzucają zbędne „graty”, inni decydują się na remonty, a ktoś nawet „dziurę se wyburzył w ścianie”.

Ciekawe, czy po 20 kwietnia ściany będą mniej przytłaczać.

Autorka: Agnieszka Marczak

Tekst powstał na podstawie ankiety „Nasze życie w czasach zarazy”, szczególnie na podstawie odpowiedzi na pytanie 4., które brzmi: „Jak się czujesz w domu?”. 


\section{Wycinek IV}

„Dzień i noc”

28.05.2020, czwartek

„Budzę się o 7:00, jem śniadanie i biorę prysznic, pracuję zdalnie 9:30-18:00, o 13:00 gotuję i jem obiad. Mam całą listę rzeczy do zrobienia (sprzątanie, drobne remonty, szycie) i wykonuję jedną z tych rzeczy po pracy. Potem czytam albo oglądam coś na YouTube. Idę spać o 22:00-23:00.”

„Źle śpię, często się budzę w nocy. Nie wysypiam się.”

„Wstaje 6:25, śniadanie 8:00, obiad 13:00, kolacja 18:45, zasypiam ok. 21:40, jem regularnie, śpię średnio.”

„5:53 pobudka, 6:00 włączam komputer (prasówka z łóżka do ok. 8:00), 8:00 praca do ok. 15:00 (w międzyczasie posiłki i krótki spacer z dziećmi), 17:00 ćwiczenia z rodziną (filmy z YT), 18:00 czytanie; kolacja, 20:00 rodzinne oglądanie telewizji (np. wiadomości ze świata, różne filmy czy spektakle; zwiedzanie muzeów)”.

„Kompletna rozwałka”.

O rytm dnia pytamy na samym początku kwestionariusza, to pierwsze dwa pytania (o to, jak wygląda nasz codzienny rytm i czy zmienił się w zawiązku z epidemią).

Wygląda na to, że staramy się utrzymać każdego dnia jakiś porządek, konkretną kolejność czynności. Staramy się, „żeby nie zwariować”, bo „inaczej tego nie ogarnę”, bo obowiązki się spiętrzyły, albo walczymy w ten sposób z brakiem motywacji i monotonią. Tworzymy grafiki, harmonogramy, ustawiamy budziki, planujemy godziny i minuty spędzone na pracy, czytaniu, przeglądaniu wiadomości, ćwiczeniach fizycznych, oglądaniu YouTube’a i Netflixa. Bywa, że chcemy ambitnie i ciekawie, bywa też, że nie mamy na nic siły, ani ochoty. Czasem sobie wyrzucamy, że „kolejny dzień zmarnowany”, czasem odpuszczamy, a czasem cieszymy się, że „jest jakby spokojniej, bardziej naturalnie”: „Nareszcie jem, kiedy jestem głodna, a nie kiedy jest przerwa w pracy”, „W moim rytmie jest mniej pośpiechu, bo w tych dniach mniej od siebie wymagam. Co nie oznacza, że nie trzymam siebie samej w ryzach. Po prostu teraz to rytm dnia dostosowuję do mojego aktualnego samopoczucia. Przed zarazą też próbowałam tak postępować, ale niestety było to bardzo trudne zadanie i raczej poddawałam się reżimowi czasu i pośpiechowi”. 
Wśród odpowiedzi znajdują się opowieści o zupełnie nowym porządku. Z naszego dotychczasowego grafiku poznikały spotkania towarzyskie, wizyty w klubach sportowych, na uczelni, w szkole, dla wielu także w pracy. Niektórym obowiązków nagle przybyło, innym one niemal z dnia na dzień poznikały. Różnie radzimy sobie z tymi zmianami, różne też mają dla nas znaczenie i konsekwencje. Mogą być okazją, by lepiej przyjrzeć się samemu/samej sobie, zadbać o własne potrzeby, nareszcie zwolnić: „rytm dnia wyznaczają mi posiłki i bardziej niż zwykle celebruję ich przygotowanie i spożywanie.”, „więcej czasu poświęcam modlitwie i medytacji”. Mogą też powodować niepokój, wprowadzać chaos: „mam znacznie mniej pracy, co przy zatrudnieniu w małej prywatnej firmie nie wróży nic dobrego”, „mój rytm dnia, to brak rytmu”, „trudniej mi się skoncentrować na tym, co robię, więcej się martwię”.

Pojawiają się też opowieści o zmianie niewielkiej lub zupełnym jej braku: „Nic szczególnego się nie zmieniło, jedyna różnica, jaka przychodzi mi do głowy, to że teraz dużo częściej myję ręce”, „jedyna zmiana, to brak spotkań po pracy”, „wszystko tak, jak wcześniej”.

Wiele osób pisze o płynności czasu, o rozmytych granicach, o pracy rozlewającej się na czas wolny, o czasie wolnym rozlewającym się na pracę: „Programowanie ma to do siebie, że bardzo łatwo uciec od niego w media społecznościowe, serwisy informacyjne czy inne ciekawe mniej lub bardziej naukowe materiały. Toteż praca się przeciąga do 3 w nocy. I tak jem, śpię i pracuję na przemian”. Dni tygodnia też zdają się już mieszać: „Odczuwam jakby to był weekend, tylko, że z dodatkową pracą”.

Wielu z nas przestawiło się na późniejsze godziny: później wstajemy, później zaczynamy i kończymy pracę, później też zasypiamy. Jak już zasypiamy, co nie wszystkim przychodzi łatwo, to śpimy: „jak niemowlę”, „,bardzo dobrze”, „nie najlepiej”, „ciągle się budzę”, „mam bobasa w domu, który mnie budzi”, „śpię źle, jak zawsze” i śnimy: „często śni mi się, że trwa epidemia i jestem zamknięta w domu”, „czasami źle śpię, śni mi się cała sytuacja, wtedy wcześniej wstaję”, „śpię dobrze, ale śnią mi się zmarli”, „brakuje mi pizzy, bo boję się ją zamawiać z okolicznej pizzerii. Śni mi się jej smak. Pizza z krewetkami i sosem...”.

28.05.2020

Autorka: Olga Błaszczyńska 
Tekst powstał na podstawie odpowiedzi na pytanie nr 1: „Jaki jest rytm Twojego dnia od momentu ogłoszenia stanu epidemii? (O której wstajesz? Jesz śniadanie? Obiad? Kolację? O której zasypiasz? Czy dobrze śpisz? Czy jesz regularnie?)” oraz pytanie nr 2: „Czy coś się zmieniło w Twoim rytmie dnia? Jeśli tak, to co?”.

\section{Co dalej z „Naszym życiem”?}

W kwestionariuszach respondentki i respondenci podzielili się swoimi doświadczeniami i przeżyciami czasu pandemii. Często były to opowieści intymne, nie zawsze łatwe, niekiedy stawiające nas w pozycji osób, które powinny się wyraźnie ustosunkować do tego, co czytają. W kwestionariuszach pojawiły się bowiem opowieści o przemocy domowej, opowieści osób, które w czasie społecznej kwarantanny są skazane na przebywanie z oprawcą całą dobę, bez możliwości ucieczki. Wiedzieliśmy, że musimy w jakiś sposób zareagować. Dlatego napisaliśmy jeden „Wycinek”, w którym podaliśmy adresy, pod którymi osoby doświadczające przemocy mogą szukać pomocy.

Szybko stało się dla nas jasne, że w anonimowej formie kwestionariusza wiele osób znalazło ujście dla emocji oraz sposób na zwierzenie się z trudnych doświadczeń. Niektórzy z respondentów pisali, że wypełnienie kwestionariusza pomogło im uporządkować wiele spraw, niektórym „zrobiło się nawet lepiej”. Uważam, że Muzeum Etnograficzne ze względu na to, że jest instytucją kultury angażującą publiczność w swoje działania, jest niejako poza dyskusją, która toczy się w środowisku etnografów/ antropologów, czyli czy antropologia powinna być nauką zaangażowaną. W moim odczuciu, etnografia muzealna musi taka być. Nie mam tu na uwadze zależności muzeum od aktualnej polityki kulturowej państwa, a potrzebę nieustannego reagowania muzeum etnograficznego na potrzeby obecnej i potencjalnej publiczności. Poprzez współpracę i działania nakierowane na odbiorców, muzeum musi mieć stale otwarte oczy i uszy na to, co ludzie mówią i robią. Muzeum etnograficzne pełni więc rolę świadka rzeczywistości. A „bycie świadkiem” jest już pewnym wyborem moralnym, zobowiązującym muzeum do refleksji, komentarza i zaangażowania w to, co się w społeczeństwie wydarza ${ }^{6}$.

${ }^{6}$ Więcej o tym pisała Nancy Scheper-Hughes [1995; 2010]. 
Dlatego biorąc pod uwagę treści, które pojawiły się w kwestionariuszu „Nasze życie w czasach zarazy”, poczuliśmy, że dalsze działania związane z pozyskanymi danymi chcemy podejmować wraz z nasza publicznością. Tym razem w formie dla Muzeum najbardziej naturalnej, a mianowicie na wystawie. Ogłosiliśmy więc zbiórkę pt. „Kolekcja w kwarantannie”, w której zapraszamy do dzielenia się opowieściami o rzeczach, które w trakcie pandemii nabrały nowych znaczeń.

Zebrane opowieści zostaną wpierw zamieszczone na wirtualnej wystawie „Kolekcji”. Będzie ona miała charakter szkicu stworzonego wraz z publicznością, projektu wystawy, która w przyszłości będzie miała miejsce już w siedzibie Muzeum.

\section{Bibliografia}

\section{Scheper-Hughes Nancy}

1995: The Primacy of the Ethical: Propositions of a Militant Anthropology, „Current Anthropology”, vol. 36, no. 3.

2010: Prymat etyki. Perspektywa walczacej antropologii, tłum. K. Liszka, [w:] Badania $w$ działaniu. Pedagogika i antropologia zaangażowana, red. D. Gołębniak, H. Cervinkova, Wrocław: Wydawnictwo Naukowe Dolnośląskiej Szkoły Wyższej.

\section{Agnieszka Marczak}

\section{Our Life in the Times of the Pandemic. A Few Words About the Project}

Our Life in the Times of the Pandemic. A Few Words About the Project reports on the research activities of the Ethnographic Museum in Krakow after the announcement of the COVID-19 pandemic by the World Health Organization in March 2020. Then the Museum created the project under the name „Our Life in the times of the Pandemic” as an answer to the question of documenting a rapidly changing reality in the pandemic. As part of this initiative, an on-line questionnaire was created, consisting of 45 questions concerning, inter alia: rhythm of everyday life, work, studies, social life. There were also questions whether the perception of home and relationships with other people have changed during the pandemic, as well as questions about the images from the pandemic that will stay in your memory for a long time. The Museum gathered over 1500 responses and on that basis created so-called „Wycinki” - excerpts from the research. Some of them are presented in this article.

Key words: Ethnographic Museum in Krakow, COVID-19 pandemic, research 
